\title{
Streptomyces koyangensis sp. nov., a novel actinomycete that produces 4-phenyl-3-butenoic acid
}

\author{
Jee Yeon Lee, Jung Yeop Lee, Ho Won Jung and Byung Kook Hwang \\ Laboratory of Molecular Plant Pathology, College of Life and Environmental Sciences, Korea \\ University, Seoul 136-713, Korea
}

Borrespondence
bkhwng Kook Hwang
bkorea.ac.kr
The genus Streptomyces proposed by Waksman \& Henrici (1943) for aerobic, spore-forming actinomycetes has been classified into different species based on morphology and cell-wall chemotaxonomic characteristics of the organisms. Streptomyces species, Gram-positive soil bacteria, have distinct features such as high DNA G $+C$ content, the presence of LL-diaminopimelic acid (LL-DAP) and the absence of characteristic sugars in the cell wall (Anderson \& Wellington, 2001). In addition, Streptomyces species produce extensively branched substrate and aerial mycelia (Locci, 1989). More than 500 Streptomyces species and subspecies have been described, the largest number of any bacterial genus (Hain et al., 1997).

Streptomycetes are the most prolific producers of various bioactive compounds, such as antibiotics (Okami \& Hotta, 1988; Berdy, 1995). During the screening of antifungal metabolites for plant chemotherapeutic agents, we isolated a variety of actinomycete strains that are active against some plant-pathogenic fungi and oomycetes from vegetative soil in Korea (Lee \& Hwang, 2002). Among them, Streptomyces sp. strain VK-A60 ${ }^{\mathrm{T}}$, isolated from soil in a radish field in Korea, produced the antibiotic 4-phenyl-3-butenoic acid,

Abbreviations: LL-DAP, LL-diaminopimelic acid; ISP, International Streptomyces Project; RAPD, random amplified polymorphic DNA; TBR, tree bisection-reconnection.

The GenBank/EMBL/DDBJ accession number for the 16S rRNA gene sequence of Streptomyces koyangensis VK-A60 ${ }^{\top}$ is $\mathrm{AY}^{\mathrm{V}} 079156$.

Detailed characteristics of the strains analysed in this study are available as supplementary material in IJSEM Online. which exhibited antifungal activity against plant-pathogenic fungi in vitro and in vivo (Lee, 2002).

Here, strain VK-A60 ${ }^{\mathrm{T}}$ was subjected to a polyphasic taxonomic analysis. Based on morphological, physiological, phylogenetic and molecular evidence, strain $\mathrm{VK}-\mathrm{A} 60^{\mathrm{T}}$ is considered to represent a novel species, Streptomyces koyangensis sp. nov.

Strain VK-A60 ${ }^{\mathrm{T}}$, which produces 4-phenyl-3-butenoic acid (Lee, 2002), was isolated from soil collected from radishgrowing fields at Koyang, Korea. The reference strains Streptomyces canescens KCCM $40569^{\mathrm{T}}\left(=\mathrm{DSM} 40001^{\mathrm{T}}\right)$, Streptomyces coelicolor KCCM $40636^{\mathrm{T}}\left(=\mathrm{DSM} 40233^{\mathrm{T}}\right)$, Streptomyces felleus KCCM 40499 ${ }^{\mathrm{T}}$ (=DSM $\left.40130^{\mathrm{T}}\right)$, Streptomyces griseus subsp. griseus KCCM 32410 (=IFO 12875), Streptomyces limosus KCCM $40500^{\mathrm{T}}$ (=DSM $40131^{\mathrm{T}}$ ), Streptomyces odorifer KCCM $40694^{\mathrm{T}}$ (=DSM $\left.40347^{\mathrm{T}}\right)$, Streptomyces sampsonii KCCM $40365^{\mathrm{T}}(=$ ATCC $25495^{\mathrm{T}}$ ) and Streptomyces somaliensis KCCM 40354 (=DSM 40267) were obtained from the Korean Culture Center of Microorganisms (KCCM), Seoul, Korea. Strain VK-A $60^{\mathrm{T}}$ and the reference strains were grown at $28^{\circ} \mathrm{C}$ on yeast extract/malt extract agar and stored in $15 \%$ glycerol yeast extract $/$ malt extract at $-70{ }^{\circ} \mathrm{C}$ until used.

The morphology of the spore chain and the spore surface ornamentation of strain VK-A60 ${ }^{\mathrm{T}}$ were examined by light and scanning electron microscopy of 14-day-old cultures on inorganic salt/starch agar as described by Williams \& Davies (1967). The morphological categorization suggested by Pridham et al. (1958) was employed using the section 
terminology of the ISP (International Streptomyces Project) (Shirling \& Gottlieb, 1969). The cultural properties of strain VK-A60 ${ }^{\mathrm{T}}$ were evaluated according to the guidelines of the ISP as described by Shirling \& Gottlieb (1966) and Locci (1989). Strain VK-A60 ${ }^{\mathrm{T}}$ was examined for physiological and biochemical features as described by Shirling \& Gottlieb (1966), Williams et al. (1983) and Locci (1989). The isomers of DAP in the whole cell hydrolysates were analysed by TLC (Lee \& Hwang, 2002). Cellular fatty acids were prepared and analysed using the method of Guckert et al. (1991). The DNA G $+C$ content of strain VK-A60 ${ }^{\mathrm{T}}$ was determined using the thermal denaturation method of Marmur \& Doty (1962). The $T_{\mathrm{m}}$ value was measured by UV spectroscopy (UV/Visible spectrophotometer, Pharmacia Biotech).

Genomic DNA of strain VK-A60 ${ }^{\mathrm{T}}$ was isolated as described by Pospiech \& Neumann (1995). The 16S rRNA gene sequence was amplified using modified universal primers, fD1 (AGAGTTTGATCCTGGG) and rP2 (ACGGCTACCTTGTTACGACTT) (Weisburg et al., 1991). The PCR products were ligated into the PCR2.1-TOPO vector (Invitrogen) and transformed into Escherichia coli TOP 10 (Invitrogen). The 16S rRNA gene sequence of strain VK$\mathrm{A} 60^{\mathrm{T}}$ inserted into the plasmid vector was sequenced on an ABI310 automatic DNA sequencer (Applied Biosystems) using Big Dye terminator cycle sequencing ready reaction kits (PE Applied Biosystems). DNA sequence analysis was performed using the BLAST network services at the NCBI (Altschul et al., 1997) and DNASTAR software program version 4.03 (DNASTAR, Inc.).

The nearly complete 16S rRNA gene sequence of strain VK$\mathrm{A} 60^{\mathrm{T}}$ was aligned with other Streptomyces nucleotide sequences using the CLUSTAL $\mathrm{W}$ program version 1.7 (Thompson et al., 1994). Phylogenetic analyses were performed according to the neighbour-joining method (Saitou \& Nei, 1987) and the maximum-parsimony method (Fitch, 1971) using PAUP* version 4b10 (Swofford, 2002). Maximum-parsimony analysis was performed with the heuristic search option with random addition sequences, branch swapping by tree bisection-reconnection (TBR) and MAXTREES set at 100. Gaps were treated as missing data and all nucleotide substitutions were equally weighted and unordered. The consistency index and retention index were calculated for all parsimony trees (Kluge \& Farris, 1969; Farris, 1989). Relative robustness of individual branches was estimated by bootstrapping, using 1000 replicates, with heuristic searches, branch swapping by TBR and MAXTREES set at 100. For neighbour-joining analysis, the data analysed by the Hasegawa-Kishino-Yano (HKY85) distance model (Hasegawa et al., 1985) were used for the construction of the neighbour-joining tree. To determine the support for each clade, bootstrap analysis was performed with 1000 replications and MAXTREES set at 10 . Trees were rooted using the TREEVIEW program, version 1.6.6.

PCR amplifications were carried out in $50 \mu \mathrm{L}$ volumes for random amplified polymorphic DNA (RAPD) analysis. The
PCR mixture contained 400 ng DNA, $0 \cdot 125 \mu \mathrm{M} \mathrm{MgCl}_{2}$, $0.25 \mu \mathrm{M}$ dNTPs (Takara), $0.125 \mu \mathrm{M}$ primer, $1.5 \mathrm{U}$ Taq DNA polymerase (Takara) and the appropriate amount of $10 \times$ buffer (Takara). DMSO was added to the PCR mixture to give a concentration of $10 \%$. Amplification was performed in a DNA thermal cycler programmed for $4 \mathrm{~min}$ at $95^{\circ} \mathrm{C}, 40$ cycles of $40 \mathrm{~s}$ at $94^{\circ} \mathrm{C}, 45 \mathrm{~s}$ at $38^{\circ} \mathrm{C}$ and $90 \mathrm{~s}$ at $72{ }^{\circ} \mathrm{C}$ and a final extension for $5 \mathrm{~min}$ at $72{ }^{\circ} \mathrm{C}$. The oligonucleotide primers AM50 (CAGGAAACAGCTATGAC), AM62 [GTTTCGGTGGTCAT(AT)GCGT(TAG)AGG], AM63 [CCT(CTA)ACGC(AT)ATGACCACGAAAC] (Mehling et al., 1995) and 70-34 (GGACCGCTAG) (Roberts \& Crawford, 2000) were synthesized by GenoTech Corp. After separation by agarose gel electrophoresis, the amplified fragments were visualized by staining with ethidium bromide solution and were photographed under UV light.

DNA-DNA hybridization between strain VK-A60 ${ }^{\mathrm{T}}$ and comparative strains S. griseus subsp. griseus IFO 12875, S. canescens DSM $40001^{\mathrm{T}}$, S. coelicolor DSM $40233^{\mathrm{T}}$, S. sampsonii ATCC $25495^{\mathrm{T}}$, S. odorifer DSM $40347^{\mathrm{T}}$, S. limosus DSM $40131^{\mathrm{T}}$, S. felleus DSM $40130^{\mathrm{T}}$ and S. somaliensis DSM 40267 was performed according to the method of Chung et al. (1999).

Strain VK-A $60^{\mathrm{T}}$ produced Rectiflexibiles spore chains containing more than 10 spores per chain. The spores were spherical in shape and $1.2 \mu \mathrm{m}$ in diameter with a smooth surface. A scanning electron micrograph of spore chains of strain VK-A60 ${ }^{\mathrm{T}}$ cultured on inorganic salts/starch agar is available as Supplementary Fig. A in IJSEM Online. Aerial mycelia proliferated well on most of the ISP culture media. The colour of the substrate mycelia was brown. Soluble pigments were produced. Strain VK-A60 ${ }^{\mathrm{T}}$ grew well on yeast extract/malt extract agar (ISP2), oatmeal agar (ISP3), inorganic salts/starch agar (ISP4), peptone/yeast extract iron agar (ISP6) and tyrosine agar (ISP7).

Whole-cell hydrolysates contained LL-DAP as a diagnostic diamino acid of the cell-wall peptidoglycan. The $\mathrm{G}+\mathrm{C}$ content of the genomic DNA was $67 \cdot 8 \mathrm{~mol} \%$. The fatty acid composition of strain VK-A $60^{\mathrm{T}}$ is shown in Supplementary Table A in IJSEM Online. The predominant cellular fatty acids were 12-methyltetradecanoic acid (anteiso- $\mathrm{C}_{15: 0}$ ), 14methylpentadecanoic acid (iso- $\mathrm{C}_{16: 0}$ ) and hexadecanoic acid $\left(\mathrm{C}_{16: 0}\right)$. The morphological and chemical properties of strain VK-A60 ${ }^{\mathrm{T}}$ were consistent with those of the genus Streptomyces (Locci, 1989; Manfio et al., 1995) (Table 1). In particular, strain VK-A60 ${ }^{\mathrm{T}}$ produced the antifungal compound 4-phenyl-3-butenoic acid in cell cultures (Lee, 2002).

The nearly complete $16 \mathrm{~S}$ rRNA gene sequence (1488 nt) of strain VK-A60 ${ }^{\mathrm{T}}$ was compared to that of Streptomyces species deposited in the GenBank database. In the phylogenetic tree of 29 Streptomyces species, strain VK-A60 ${ }^{\mathrm{T}}$ was placed in the clade with S. griseus subsp. griseus, S. felleus, S. odorifer, S. coelicolor, Streptomyces albidoflavus, S. somaliensis, S. limosus, S. canescens, S. sampsonii, Streptomyces resistomycificus and Streptomyces griseochromogenes (Fig. 1). $16 \mathrm{~S}$ 
Table 1. Morphological, physiological and biochemical characteristics of strain $\mathrm{VK}-\mathrm{A} 60^{\top}$ and phylogenetically related Streptomyces species

Strains/species: 1, S. koyangensis sp. nov. VK-A60 ${ }^{\mathrm{T}}$; 2, S. albidoflavus 3, S. canescens; 4, S. coelicolor; 5, S. felleus; 6, S. griseus; 7, S. limosus; 8, S. odorifer; 9, S. sampsonii; 10, S. somaliensis. Data for reference species were taken from Shirling \& Gottlieb (1966, 1969), Nonomura (1974) and Williams et al. (1989). +, Positive; -, negative; D, doubtful; V, variable; ND, no data available. All species exhibit Rectiflexibiles spore chains with smooth spore surfaces and are negative for growth on inositol and raffinose and positive for growth on xylose and mannitol as sole carbon sources.

\begin{tabular}{|c|c|c|c|c|c|c|c|c|c|c|}
\hline Characteristic & 1 & 2 & 3 & 4 & 5 & 6 & 7 & $8^{*}$ & 9 & 10 \\
\hline DNA G $+C$ content $(\mathrm{mol} \%)$ & $67 \cdot 8$ & 70 & ND & ND & ND & 71 & ND & ND & ND & ND \\
\hline Aerial mass colour $\dagger$ & $\mathrm{W} / \mathrm{Y}$ & $\mathrm{W} / \mathrm{G}$ & $\mathrm{Y}$ & $\mathrm{Y}$ & $\mathrm{Y}$ & Y & $\mathrm{Y}$ & $\mathrm{Y}$ & $\mathrm{Y} / \mathrm{G}$ & PY \\
\hline \multicolumn{11}{|l|}{ Reverse-side pigment on: $\$$} \\
\hline ISP2 & B & - & - & $\mathrm{LB} / \mathrm{SB}$ & - & - & - & - & - & - \\
\hline ISP3 & B & - & - & B & - & - & - & - & $\mathrm{Y} / \mathrm{YB}$ & - \\
\hline ISP4 & B & - & GY & $\mathrm{LB} / \mathrm{SB}$ & - & - & - & - & $\mathrm{Y} / \mathrm{YB}$ & - \\
\hline ISP5 & $\mathrm{C} / \mathrm{LB}$ & - & - & $\mathrm{LB} / \mathrm{SB}$ & - & - & - & - & - & - \\
\hline Sucrose & - & - & - & - & - & - & - & $-1+$ & - & - \\
\hline D-Glucose & + & + & + & + & $\mathrm{V}$ & + & + & + & + & + \\
\hline Antibiotic producedll & $\begin{array}{l}\text { 4-Phenyl-3- } \\
\text { butenoic acid }\end{array}$ & ND & Asconsin & ND & Pikromycin & $\mathrm{DAO}$ & Limocrocin & ND & ND & $\mathrm{ND}$ \\
\hline
\end{tabular}

${ }^{*}$ S. odorifer strain CBS differs from strain IMRU in melanin production, carbon utilization, darkening of PYIA (peptone/yeast/iron agar) and TYB (tryptone yeast broth), but not TA (tyrosine agar). Strain CBS utilizes rhamnose, but not sucrose, whereas strain IMRU uses sucrose, but not rhamnose.

$\dagger$ †, Grey; PY, pale yellow; w, white; Y, yellow.

¥Melanin pigment is produced in ISP7 medium, but not in ISP6.

$\S B$, Brown; C, creamy; GY, greenish yellow; LB, light brown; SB, strong, dark brown; Y, yellow; YB, yellowish brown.

IIDAO, Deacetoxycephalosporin.

rRNA gene sequence similarity among these organisms was $99 \%$, which corresponds to approximately $15 \mathrm{nt}$ differences in 1488 bases. These 11 Streptomyces species were grouped into the clusters of S. griseus subsp. griseus and S. albidoflavus in the phylogenetic tree generated using the neighbourjoining algorithm (Saitou \& Nei, 1987) (Fig. 1). The close relationships between strain $\mathrm{VK}-\mathrm{A} 60^{\mathrm{T}}$ and these 11 species were confirmed by maximum-parsimony methods (Fitch, 1971). Strain VK-A60 ${ }^{\mathrm{T}}$ forms a distinct phylogenic line distant from the two clusters of S. griseus subsp. griseus and S. albidoflavus in the tree. The position of strain $\mathrm{VK}-\mathrm{A} 60^{\mathrm{T}}$ in the phylogenetic tree was not affected by either the treemaking algorithm or the outgroup strains used. These findings suggest that strain $\mathrm{VK}-\mathrm{A} 60^{\mathrm{T}}$ represents a novel species that is closely related to the 11 Streptomyces species, having a high $16 \mathrm{~S}$ rRNA gene sequence similarity. The designation of strain VK-A $60^{\mathrm{T}}$ as a separate genomic species was suggested by the bootstrap value $(96 \%)$ in the neighbour-joining tree based on the nearly complete $16 \mathrm{~S}$ rRNA gene sequence data.

To establish further the classification of strain VK-A $60^{\mathrm{T}}$, RAPD analysis was performed using primers of various lengths with varying $\mathrm{G}+\mathrm{C}$ contents. RAPD analysis yielded 6-13 bands for each Streptomyces strain and specific banding patterns with the different primer pairs. In general, primers AM50, AM62 and AM63 separated nine strains into three groups according to their banding patterns. In the RAPD profile, S. griseus subsp. griseus formed one group (group I), and S. canescens, S. coelicolor, S. felleus, S. limosus, S. odorifer, S. somaliensis and S. sampsonii formed another (group II). Strain VK-A60 ${ }^{\mathrm{T}}$, in group III, exhibited a clearly distinguishable RAPD banding pattern. In particular, unique bands of $0.4,3.0$ and $0.9 \mathrm{~kb}$ were generated from strain $\mathrm{VK}-\mathrm{A} 60^{\mathrm{T}}$ by the primers AM50, AM62 and AM63, respectively. When the primer 70-34 (with low 


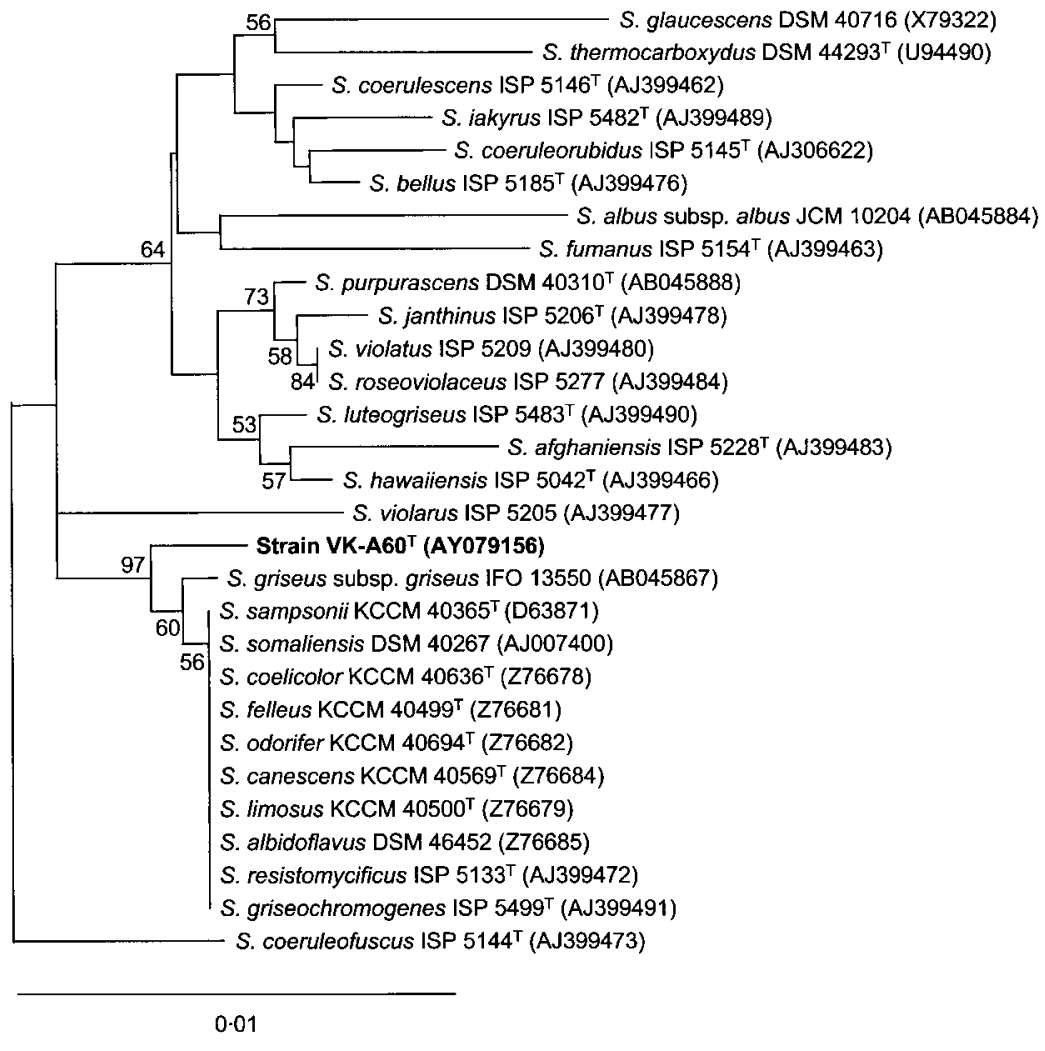

Fig. 1. Neighbour-joining phylogenetic tree of strain VK-A60 ${ }^{\top}$ and 28 Streptomyces species based on nearly complete $16 \mathrm{~S}$ rRNA gene sequences (1488 nt). Numbers at nodes indicate levels of bootstrap support (\%) based on a neighbour-joining analysis of 1000 resampled datasets; only values $>50 \%$ are given. $\mathrm{NCBI}$ accession numbers are given in parentheses. Bar, 0.01 nucleotide substitutions per site.

DNA G + C content) was used, all strains tested generated diverse RAPD banding patterns. The RAPD banding patterns are available as Supplementary Fig. B in IJSEM Online.

DNA-DNA hybridization analysis was carried out between strain VK-A60 ${ }^{\mathrm{T}}$ and closely related strains selected from the phylogenetic data. The levels of DNA-DNA hybridization between strain VK-A60 ${ }^{\mathrm{T}}$ and S. griseus subsp. griseus, S. canescens, S. coelicolor, S. sampsonii, S. odorifer, S. limosus, S. felleus and $S$. somaliensis were $68 \cdot 5,55 \cdot 2,20 \cdot 8,64 \cdot 0,34 \cdot 4$, $66 \cdot 8,25 \cdot 6$ and $57 \cdot 5 \%$, respectively. DNA-DNA relatedness values below $80 \%$ have been recommended for the recognition of novel genomic species of Streptomyces (Labeda, 1993, 1996, 1998). The DNA-DNA relatedness values determined here are available as Supplementary Table B in IJSEM Online.

Strain VK-A60 ${ }^{\mathrm{T}}$ was clearly distinguished from the phylogenetically related Streptomyces strains by the formation of melanin, soluble pigments, reverse-side pigments and production of antibiotics (Table 1). However, morphological features of the aerial mycelium and carbon-source utilization of strain VK-A $60^{\mathrm{T}}$ were similar to those of these closely related strains.

Based on the combination of phenotypic characteristics and genotypic data, we propose the name Streptomyces koyangensis sp. nov. for this organism.

\section{Description of Streptomyces koyangensis sp. nov.}

Streptomyces koyangensis (ko.yang.en'sis. N.L. masc. adj. koyangensis pertaining to Koyang, Republic of Korea, the geographical origin of the type strain).

Aerobic, Gram-positive, non-motile actinomycete. Spore chains containing 10 or more spores per chain are Rectiflexibiles. Spores are spherical $(1 \cdot 2 \mu \mathrm{m}$ in diameter $)$ with a smooth surface. Whole-cell hydrolysates contain LL-DAP. The $\mathrm{G}+\mathrm{C}$ content of the genomic DNA is $67 \cdot 8 \mathrm{~mol} \%$. The predominant cellular fatty acids are anteiso- $\mathrm{C}_{15: 0}$ $(16 \cdot 54 \%)$, iso- $\mathrm{C}_{16: 0}(28 \cdot 77 \%)$ and $\mathrm{C}_{16: 0}(11 \cdot 60 \%)$. In addition, anteiso- $\mathrm{C}_{17: 0}(9 \cdot 01 \%)$, iso- $\mathrm{C}_{14: 0}(8 \cdot 84 \%)$, iso$\mathrm{C}_{15: 0}(7 \cdot 02 \%), \mathrm{C}_{17: 0}$ cyclo $(4 \cdot 54 \%)$, anteiso- $\mathrm{C}_{17: 1}$ $(3.23 \%)$, iso- $\mathrm{C}_{17: 0}(1.94), \mathrm{C}_{14: 0}(1.33 \%)$, iso- $\mathrm{C}_{16: 1}$ $(1 \cdot 86 \%)$ and $\mathrm{C}_{16: 1}$ cis $9(2 \cdot 57)$ were detected. Grows well on yeast extract/malt extract agar (ISP2), oatmeal agar (ISP3), inorganic salts/starch agar (ISP4), peptone/yeast extract iron agar (ISP6) and tyrosine agar (ISP7). Does not grow well on ISP5 medium. The spore mass is white to grey and the reverse sides of colonies are brown on most agar media. Aerial mycelia are abundant on most of these media. The colour of substrate mycelium is pale brown to dark brown. Production of spores on ISP4 is prolific. Melanin pigments are produced on ISP6 and ISP7. As the sole carbon source, it utilizes L-arabinose, D-fructose, mannitol and xylose for growth, but not adonitol, dextran, 
meso-inositol, D-melezitose, D-melibiose, raffinose, Lrhamnose, sucrose or xylitol. As a nitrogen source, utilizes L-cysteine, L-histidine, L-phenylalanine and L-valine. However, it cannot utilize DL- $\alpha$-amino- $n$-butyric acid or L-hydroxyproline. Degrades casein, elastin, aesculin, gelatin, starch, tyrosine and xanthine, but not cellulose. Pectin hydrolysis, nitrate reduction and $\mathrm{H}_{2} \mathrm{~S}$ production are positive, whereas lecithinase, lipolysis and hippurate hydrolysis are negative. The strain grows in the presence of 4,7 and $10 \%$ sodium chloride but not $13 \%$. It grows in $0.02 \%$ $\mathrm{NaN}_{3}$ and $0.001 \%$ thallous acetate, but not in $0.1 \%$ phenol or $0.001 \%$ potassium tellurite. The strain is resistant to penicillin $\mathrm{G}$, but sensitive to neomycin, rifampicin and oleandomycin. Produces 4-phenyl-3-butenoic acid, which inhibits the mycelial growth of several plantpathogenic fungi, such as Alternaria mali, Cladosporium cucumerinum, Colletotrichum gloeosporioides, Colletotrichum orbiculare, Magnaporthe grisea and Fusarium oxysporum $\mathrm{f}$. sp. cucumerinum.

The type strain is $\mathrm{VK}-\mathrm{A} 60^{\mathrm{T}}\left(=\mathrm{KCCM} 10555^{\mathrm{T}}=\mathrm{NBRC}\right.$ $\left.100598^{\mathrm{T}}\right)$.

\section{Acknowledgements}

This study was supported by a grant (\# CG 1432) from the Crop Functional Genomics Center of the 21st Century Frontier Research Program funded by the Ministry of Science and Technology and a grant from the Center for Plant Molecular Genetics and Breeding Research, Korea. We thank Stuart Timmis for critically reviewing the manuscript.

\section{References}

Altschul, S. F., Madden, T. L., Schäffer, A. A., Zhang, J., Zhang, Z., Miller, W. \& Lipman, D. J. (1997). Gapped BLAST and PSI-BLAST: a new generation of protein database search programs. Nucleic Acids Res 25, 3389-3402.

Anderson, A. S. \& Wellington, E. M. H. (2001). The taxonomy of Streptomyces and related genera. Int J Syst Evol Microbiol 51, 797-814.

Berdy, J. (1995). Are actinomycetes exhausted as a source of secondary metabolites? In Proceedings of the 9th International Symposium on the Biology of Actinomycetes, part I, pp. 3-23. New York: Allerton.

Chung, Y. R., Sung, K. C., Mo, H. K., Son, D. Y., Nam, J. S., Chun, J. S. \& Bae, K. S. (1999). Kitasatospora cheerisanensis sp. nov., a new species of the genus Kitasatospora that produces an antifungal agent. Int J Syst Bacteriol 49, 753-758.

Farris, J. S. (1989). The retention index and the rescaled consistency index. Cladistics 5, 417-419.

Fitch, W. M. (1971). Towards defining the course of evolution: minimum change for specific tree topology. Syst Zool 20, 406-416.

Guckert, J. B., Ringelberg, D. B., White, D. C., Hanson, R. S. \& Bratina, B. J. (1991). Membrane fatty acids as phenotypic markers in the polyphasic taxonomy of methylotrophs within the proteobacteria. J Gen Microbiol 137, 2631-2641.

Hain, T., Ward-Rainey, N., Kroppenstedt, R. M., Stackebrandt, E. \& Rainey, F. A. (1997). Discrimination of Streptomyces albidoflavus strains based on the size and the number of 16S-23S ribosomal DNA intergenic spacers. Int J Syst Bacteriol 47, 202-206.
Hasegawa, M., Kiwshino, H. \& Yano, T. (1985). Dating the humanape split by molecular clock of mitochondrial DNA. J Mol Evol 22, 160-174.

Kluge, A. G. \& Farris, J. S. (1969). Quantitative phyletics and the evolution of anurans. Syst Zool 18, 1-32.

Labeda, D. P. (1993). DNA relatedness among strains of the Streptomyces lavendulae phenotypic cluster group. Int J Syst Bacteriol 43, 822-825.

Labeda, D. P. (1996). DNA relatedness among verticil-forming Streptomyces species (formerly Streptoverticillium species). Int J Syst Bacteriol 46, 699-703.

Labeda, D. P. (1998). DNA relatedness among the Streptomyces fulvissimus and Streptomyces griseoviridis phenotypic cluster groups. Int J Syst Bacteriol 48, 829-832.

Lee, J. Y. (2002). Production, purification, and control efficacy against plant diseases of the antibiotics Vka1 and Agrl from Streptomyces sp. strain $V K-A 60^{T}$ and rhizome of Acorus gramineus. MSc thesis, Korea University, Korea.

Lee, J. Y. \& Hwang, B. K. (2002). Diversity of antifungal actinomycetes in various vegetative soils of Korea. Can J Microbiol 48, 407-417.

Locci, R. (1989). Streptomycetes and related genera. In Bergey's Manual of Systematic Bacteriology, vol. 4, pp. 2451-2452. Edited by S. T. Williams, M. E. Sharpe \& J. G. Holt. Baltimore: Williams \& Wilkins.

Manfio, G. P., Zakrzewska-Czerwinska, J., Atalan, E. \& Goodfellow, M. (1995). Towards minimal standards for the description of Streptomyces species. Biotechnologia 7-8, 242-253.

Marmur, J. \& Doty, P. (1962). Determination of the base composition of deoxyribonucleic acid from its thermal denaturation temperature. J Mol Biol 5, 109-118.

Mehling, A., Wehmeier, U. F. \& Piepersberg, W. (1995). Application of random amplified polymorphic DNA (RAPD) assays in identifying conserved regions of actinomycete genomes. FEMS Microbiol Lett 128, 119-126.

Nonomura, H. (1974). Key for classification and identification of 458 species of the Streptomycetes included in ISP. J Ferment Technol 52, 78-92.

Okami, Y. \& Hotta, K. (1988). Search and discovery of new antibiotics. In Actinomycetes in Biotechnology, pp. 33-67. Edited by M. Goodfellow, S. T. Williams \& M. Mordarski. London: Academic Press.

Pospiech, A. \& Neumann, B. (1995). A versatile quick-prep of genomic DNA from Gram-positive bacteria. Trends Genet 11, 217-218.

Pridham, T. G., Hesseltine, C. W. \& Benedict, R. G. (1958). A guide for the classification of streptomycetes according to selected groups. Placement of strains in morphological sections. Appl Microbiol 6, 52-79.

Roberts, M. A. \& Crawford, D. L. (2000). Use of randomly amplified polymorphic DNA as a means of developing genus- and strainspecific Streptomyces DNA probes. Appl Environ Microbiol 66, 2555-2564.

Saitou, N. \& Nei, M. (1987). The neighbor-joining method: a new method for reconstructing phylogenetic trees. Mol Biol Evol 4, 406-425.

Shirling, E. B. \& Gottlieb, D. (1966). Methods for characterization of Streptomyces species. Int J Syst Bacteriol 16, 313-340.

Shirling, E. B. \& Gottlieb, D. (1969). Cooperative description of type cultures of Streptomyces. IV. Species descriptions from the second, third and fourth studies. Int J Syst Bacteriol 19, 391-512. 
Swofford, D. L. (2002). PAUP* Phylogenetic Analysis Using Parsimony ( ${ }^{*}$ and Other Methods), version 4b10. Sunderland, MA: Sinauer Associates.

Thompson, J. D., Higgins, D. G. \& Gibson, T. J. (1994). CLUSTAL W: improving the sensitivity of progressive multiple sequence alignment through sequence weighting, position-specific gap penalties and weight matrix choice. Nucleic Acids Res 22, 4673-4680.

Waksman, S. A. \& Henrici, A. T. (1943). The nomenclature and classification of the actinomycetes. J Bacteriol 46, 337-341.
Weisburg, W. G., Barns, S. M., Pelletier, D. A. \& Lane, D. J. (1991). $16 \mathrm{~S}$ ribosomal DNA amplification for phylogenetic study. J Bacteriol 173, 697-703.

Williams, S. T. \& Davies, F. L. (1967). Use of a scanning electron microscope for the examination of actinomycetes. J Gen Microbiol 48, 171-177.

Williams, S. T., Goodfellow, M., Alderson, G., Wellington, E. M. H., Sneath, P. H. A. \& Sackin, M. J. (1983). Numerical classification of Streptomyces and related genera. J Gen Microbiol 129, 1743-1813. 